\title{
Financial Statements of Banks as a Source of Information About Implementation of IFRS 15: The Evidence from Poland
}

\author{
Kinga Bauer \\ Cracow University of Economics, Kraków, Poland \\ Giovanna Centorrino \\ University of Messina, Messina, Italy
}

\begin{abstract}
Banks in the economies of individual countries play the role of entities of public trust and are perceived as "too big to fail". In fact, they are exposed to risks associated with business operations. In practice, there are even instances of banks going bankrupt. Therefore, the reliability of the financial statements of a bank as a source of information about its financial condition is of particular importance. The main objective of creating IAS/IFRS and their implementation within the European Union is the strive to standardize accounting rules utilized by companies and other organizations. IFRS, as any other regulations, are subject to change over years. One of the recent changes is the introduction of IFRS 15 "Revenue from Contracts with Customers". In all entities using IAS/IFRS, communication of planned changes should involve disclosure ahead of time, regarding the analysis of their impact on the financial statements. The purpose of this paper has been to analyze whether the financial statements of banks contain any records on the impact of IFRS 15. These analyses are within the mainstream of studying how complete and prospective is the information contained in the financial statements for external users. The subjects for research are the consolidated financial statements of five major banks in Poland. As a result of research, it was found that in all studied cases, work on the implementation of IFRS 15 was observed. However, looking at every bank separately, a differentiated approach to presenting information on the standard is observed, which may be a hindrance for users of banks' financial statements.
\end{abstract}

Keywords: bank, financial statement, International Financial Reporting Standards, IFRS 15, Poland

\section{Introduction}

Banks as units of public trust have played a key role in the financial system of any country for centuries. They are specific entities which by law are entitled to raise funds in the form of cash contributions, make cash settlements and other banking activities. Due to their specificity, until recently, they were commonly considered too big or too important to fail. This opinion of banks was greatly changed during the collapse of Lehman Brothers, which is regarded as the beginning of the global economic crisis (Surdykowska, 2012). The issue of risk associated with banks' operations is reflected in recent research (e.g., Tominac \& Palijan, 2015; 2016; Zengin \& Yuksel, 2016; Wójcik-Jurkiewicz, 2015). Emphasis is put on the fact that banks are vulnerable to risk or even due to the status of "too big to fail" may be willing to bear the increased risk (Afonso, Santos, \& Traina,

Kinga Bauer, Ph.D., Department of Accounting, Cracow University of Economics. Email: kinga.bauer@uek.krakow.pl.

Giovanna Centorrino, Assistant Professor in Accounting and Business Administration, Department of Economics, University of Messina. 
2014). Not only the benefits but also the costs associated with banks' status of "too big to fail" are being analysed (e.g., Boyd \& Heitz, 2016; Brewer \& Jagtiani, 2013). Research casts doubt on whether all countries are able to save their largest banks. This results in the fact that banks may be too big to be saved (Demirgüç-Kunt \& Huizinga, 2013).

In this context, the reliability of the financial statements of a bank as a source of information about its financial condition is of particular importance. The information contained in financial statements will be of interest to a wider range of users than just to authorities of the country that permits the bank to operate. In connection with the ongoing process of globalization, the group of users of financial information of banks may also become international. In $\mathrm{EU}^{1}$ countries, banks draw up consolidated financial statements in accordance with IFRS. The Conceptual Framework for Financial Reporting (2017) stated that, a complete depiction of a financial statement should contain all information necessary for a user to understand the phenomenon being depicted, including all necessary descriptions and explanations.

IFRS, as any other regulations, are subject to change over time. One of the recent changes is the introduction of IFRS 15 "Revenue from Contracts with Customers". In 2018, it will go into effect in Poland, and definitely have an impact on accounting of banks. In order to be considered useful, a financial statement should provide information about planned changes to classification and valuation of each item in advance so as to enable the investors to respond ahead of time. High-quality financial information, useful for investors and other users of financial statements, is all the more important to entities of such great importance for the stability of the financial system as banks. In the context of these considerations, the purpose of this paper is to analyze if the financial statements of banks contain any records on the impact of IFRS 15. These analyses are within the mainstream of studying how complete and prospective is the information contained in the financial statements for external users. ${ }^{2}$ The subjects for research are the consolidated financial statements of five major banks in Poland.

Choosing financial statements of banks operating in Poland as subject of the research is intentional. Poland is still a relatively new member of the EU (since 2004), and it is obliged, like other member states, to use EU regulations also with regard to financial reporting of banks. The application of IFRS should result in high-quality financial reporting of entities which apply international rules and in the disclosure of relevant information about future changes on how to record a given entry; information which is significant to financial statement users. In times of globalization which enables free flow of capital between countries, research which increases the level of knowledge on procedures used not only has a cognitive character, but also can affect behaviour of investors on a global scale.

\section{The Main Features of the Banking System in Poland}

The banking system in Poland, which is a major part of the financial system, is patterned after the Continental model typical for countries such as Italy, France, Germany, Austria, Spain, Portugal, and Japan. ${ }^{3}$

\footnotetext{
${ }^{1}$ In some countries, all banks prepare their financial statements in accordance with IFRS. In Poland, where research has been carried out for the purpose of this paper, there is a large group of small banks (mainly cooperative banks), which prepare financial statements in accordance with the Polish Accounting Act.

${ }^{2}$ The implementation of IFRS 15 is inevitable. In this regard, notes section of financial statements considered as a complete descriptive part should, ex ante, indicate the potential changes that might come with the implementation of this standard.

${ }^{3}$ In contrast to the Continental model, the Anglo-Saxon model is characterized by a strict separation of deposit and credit banking from investment banking which related to the capital market and a strong tendency to create banks which specialize in particular areas. The Anglo-Saxon model is mainly used in countries such as the United States, Britain, Canada, and Australia.
} 
In this model, banks satisfy not only the short-term, but also long-term financial needs of stakeholders. Financial institutions are universal and universal banks combine deposit-credit banking with investment banking (e.g., Krasodomska, 2010; Cwynar \& Patena, 2010; Gostomski, 2008; Bujnowicz, 2008; Othman \& Zeghal, 2006).

In a market economy, a two-tier banking system has developed which consists of the central bank and commercial banks.

The activities of banks in Poland are strictly regulated by law. The main legal act regulating the banks' activity in Poland is the Banking Law of 29 August 1997, along with all amendments.

In Poland, the role of the central bank fulfills the Polish National Bank, which was created in 1945. Other banks can be incorporated either as state banks, cooperative banks, or banks in the form of joint-stock companies.

The only state bank in Poland is Bank Gospodarstwa Krajowego (BGK) founded in 1924. The BGK is fully owned by the State Treasury. Its role is to support governmental socio-economic programmes realised in order to facilitate entrepreneurship and infrastructural or housing investments (BGK, 2015).

In December 2016, there were 621 banking entities in Poland, including:

(1) 36 commercial banks;

(2) 27 departments of credit institutions;

(3) 558 cooperative banks. ${ }^{4}$

In spite of the fact that cooperative banks are much more numerous, they do not play a key role in the Polish banking system. That can be proved by the fact that ca. $90 \%$ of received deposits and extended loans fall to commercial banks (Krasodomska, 2015).

Cooperative banks act as cooperatives and create their own funds from shares of their members. The activities of these banks involve only small areas. These banks operate mainly in small towns and villages.

Banks in each country are a particularly important link in the financial system, also viewed in the context of its stability (e.g., Berger, Klapper, \& Turk-Ariss, 2009; Carletti \& Hartmann, 2003). In recent years, business activities of banks contributed to a significant breach of trust towards them and to an increased awareness that banks are entities which are not unconditionally secure. Restoration of the lost reputation must involve fair operations and transparency of information (Zieliński, 2013).

The role that banks play causes them to be treated as units of public trust. In Poland, the concept of "public interest entities" is clearly defined in the Act on statutory auditors and their self-government, entities authorized to audit financial statements and public supervision (Ustawa z dnia 7 maja 2009 o biegtych rewidentach $i$ ich samorzqdzie, podmiotach uprawnionych do badania sprawozdań finansowych oraz o nadzorze publicznym, 2009, No. 77, Item 649, Art. 2, Point 4). Among other such listed units are domestic banks, branches of credit institutions, and branches of foreign banks operating under the Banking Law.

Common characteristics of entities of public trust include considerable size, international activity and operating within capital groups. These features should result in the desire to ensure financial transparency, and thereby lead to drawing up and publishing high-quality financial reports (Krasodomska, 2015). These characteristics of entities of public trust in Poland refer to commercial banks and not cooperatives. In reference to the above, their financial reporting will be the focus of the latter part of this paper.

\footnotetext{
${ }^{4}$ For the needs of this paper, only the commercial banks have been analyzed.
} 


\section{IFRS as a Basis for Financial Statements of the Biggest Banks in Poland}

The main piece of legislation regulating accounting operations in Poland is the Accounting Act. The Act, in many points, refers to bank accounting, for example:

(1) Obligation of using the provisions of the Accounting Act in organisations operating under the Banking Law (Art. 2, Paragraph 1, Point 3);

(2) Definition of bank, as an undertaking operating on the basis of the provisions of the Banking Law (Art. 3, Paragraph 1, Point 2);

(3) Annex No. 2 dedicated to banks and named "The Scope of Information to be Disclosed in the Financial Statements for Banks".

Banks that prepare financial statements on the basis of the Act first apply its provisions and the Regulation of the Minister of Finance dated 1 October 2010 on specific accounting principles for banks. In Poland, there is a duality in the legal regulations concerning accounting, including accounting of banks. This duality is reflected in the fact that some units are obliged to use national Generally Accepted Accounting Principles (GAAP) as part of the IFRS. In practice, national legal regulations in Poland are used by banks of little significance for the banking sector, i.e., co-operative and smaller domestic banks (Krasodomska, 2015).

Staring 2005, after the accession into the EU, banks and entities operating in Poland which have their shares on the stock market use IFRS and the EU directives in the preparation of consolidated financial statements. Only in matters not covered by IFRS they can apply national regulations. In addition, entities (including banks), in which the parent company prepares its financial statements in accordance with IFRS, may prepare individual financial statements in accordance with IFRS. In practice, all major commercial banks in Poland prepare financial statements in accordance with IFRS.

The contents of a bank's financial statements prepared in accordance with IFRS are defined in IAS 1. A complete financial statement consists of:

(1) A statement of financial position as at the end of the period;

(2) A statement of profit or loss and other comprehensive income for the period;

(3) A statement of changes in equity for the period;

(4) A statement of cash flows for the period;

(5) Notes, comprising significant accounting policies and other explanatory information;

(6) Comparative information in respect of the preceding period;

(7) A statement of financial position as at the beginning of the preceding period when an entity applies an accounting policy retrospectively or makes a retrospective restatement of items in its financial statements, or when it reclassifies items in its financial statements.

The use of the above names is not mandatory. Banks may continue to use the previous names, e.g., "a balance sheet" instead of "a statement of financial position as at the end of the period".

The most important IFRS which affect banks' accounting (except IAS 1) are those related to financial instruments, i.e. (Krasodomska, 2015; Marcinkowska, 2007):

(1) IAS 39 and IFRS 9 which is to replace the former by 2018, which define the principles by which to record items in the balance sheet and, to evaluate financial instruments;

(2) IAS 32, its purpose is to facilitate the understanding of the significance of financial instruments recorded in the balance sheet, in reference to an entity's result and cash flow; 
(3) IFRS 7, which mandates the disclosure of information that enables an assessment of the impact of financial instruments on an entity's performance and the way it manages the risks associated with financial instruments.

The making of financial statements of banks in accordance with IFRS can be seen as difficult. The main problem arises from the fact that IFRS does not specify a model report. Unlike IFRS, Appendix 2 of the Accounting Act includes a ready-made pattern for each item of the financial statement. Another difficulty may also arise - with some entries in the statement - due to the difference in terminology between the Accounting Act and IFRS. The processes of harmonization and standardization of accounting are extremely important, as is the provision of reliable information and comparability of financial data (Wszelaki, 2014). Undoubtedly, the process of comparability of financial statements of banks which operate in the global market is made easier when they are formed in accordance with IFRS. Banks, while creating reports, should strive to provide qualitative characteristics associated with useful financial information.

The Conceptual Framework for Financial Reporting explains the qualitative characteristics of useful financial information and points outs that some financial reports also include different types of forward-looking information. One of the planned changes in the financial reporting of banks in Poland is the implementation of IFRS 15 . It is to be implemented in 2018 , but issues effected by the change may already today be included in banks' financial statements as forward-looking information.

Given this, an analysis of this standard will be conducted and later information about its potential impact on the banks' financial statements in Poland will be provided.

\section{IFRS 15 Revenue Recognition: The Joint Standard}

The idea of harmonization of accounting standards first arose in 1950 after World War II, when the reduction of differences among accounting principles used in the major capital markets worldwide was seen as a process target. Since 1990, the notion has grown and has been replaced by the concept of convergence ${ }^{5}$ that today constitutes one of the most ambitious and far-reaching efforts in financial history.

It is known that the International Financial Reporting Standards (IFRS) Foundation, an independent, non-profit private organization, through the International Accounting Standards Board (IASB), has developed a single set of international financial reporting standards (IFRSs) (Choi, Frost, \& Meek, 2002). The IFRS community continues to grow and become more complex due also to new aspects of financial reporting. Over time, the IASB has grown in importance and has, arguably, acquired the status of a private standard-setter whose activities are of primary interest for a global audience (Jorissen, Lybaert, \& Van De Poel, 2006). Instead, the United States of America follows the GAAP and the Financial Accounting Standards Board (FASB). IASB standards are different from FASB standards, and, even if differences are inevitable and sometimes appropriate, the use of two accounting systems is often expensive when investors are making financial decisions, and it creates difficulties and problems.

In the light of the above-mentioned consideration, IFRS and GAAP took the decision to develop a single set of high-quality international accounting standards.

\footnotetext{
5 "There exist several notions (or interpretations) of convergence in accounting standards. From a strict viewpoint, 'convergence' refers to the enforcement of a single set of accepted standards by several regulatory bodies, while a soft notion of 'convergence' refers to diminishing differences among accounting standards issued by several regulators" (Carmona \& Trombetta, 2010, p. 3).
} 
The beginning of the process of the IASB and U.S. GAAP convergence can be traced back to 2000, when the use of international standards was in rapid growth, and the FASB (the private sector accounting standard setter for the United States) and the IASB began to collaborate, formally.

The pursuing of convergence is seen by FASB as fully consistent with its own mission, which is to improve U.S. financial accounting for the benefit of present and future investors and other users of financial statements.

With regard to convergence, the two Boards (FASB and IASB), in consultation with other national and regional bodies, collaborated through joint projects to develop common standards and remove differences between International Standards and US GAAP, and their tactics to achieve this goal are described in two different documents: The Norwalk Agreement and the Memorandum of Understanding (MoU) originally issued in 2006 and updated in 2008 and 2010 (Barth, Landsman, Lang, \& Williams, 2012).

In September 2002, the FASB and the IASB announced plans to achieve convergence in a document called the "Norwalk Agreement". The proposal was that some detailed differences should be removed rapidly and, later, other differences gradually. However, the Memorandum of Understanding issued is considered the definitive step forward in the convergence process. The document identified the standard-setting projects that the Boards considered to be most in need of improvement in the near-term. The FASB and the IASB have recognized that their contribution to achieving the objectives regarding reconciliation requirements is in continued and measurable progress on the FASB-IASB convergence program. Both boards have affirmed their commitment to making such progress. It includes topics that are deemed critical to convergence: business combinations, consolidation, fair value measurement guidance, liabilities and equity distinctions, performance reporting, post-retirement benefits (including pensions), derecognition, financial instruments, revenue recognition, intangible assets, and leases.

In February 2013, the IASB and FASB published a high-level update on the status and time of the remaining convergence projects. One of the remaining joint projects is revenue recognition.

\section{Implementation of the New Revenue Standard}

Revenue is typically the single largest item reported in a company's income statements. As with bottom-line income, top-line revenue is significant not simply in monetary expressions, but also in the weight and meaning that investors place on it in making investment decisions. Trends and growth in a company's revenue are indicators of the company's past performance and future prospects (Zhang, 2005; Turner, 2001). The fundamental revenue recognition concept is that a company should not recognize revenues until realized or realizable and earned by the company. Thus, one of the critical issues of revenue concerns the appropriate moment in the sales cycle when revenue should be recognized. However, the timing of revenue recognition is problematic due to the complexity and diversity of the underlying revenue-generating transactions.

In the light of the earlier consideration, revenue recognition has been one of the most important issues confronting standard setters and accountants recently, and also one that holds greater difficulties both in its application and preparation.

As above-mentioned, the revenue recognition project is a joint project between the FASB and IASB. Nonetheless, it was developed by the two Boards separately in order to finalize the standard. Although the analysis of each Board's respective due process was carried out separately, the final standard is a joint standard and the Boards were asked to approve, substantially, the same Standard for publication, at the same time. 
In IFRS, the new standard should replace IAS 11 Construction Contracts and IAS 18 Revenue and the related Interpretations on Revenue Recognition; in the U.S. GAAP guidance it should supersede most of the revenue recognition requirements in Topic 605 and related guidance (FASB).

The revenue recognition standard was subjected to a long, comprehensive process to ensure that the IASB and the FASB issued a relevant and workable standard.

In December 2008, the IASB published Discussion Paper: Preliminary Views on Revenue Recognition in Contracts with Customers. It explained the boards' first views on revenue, and some of the principles proposed as the basis of a future standard. After evaluating feedback received on the discussion paper, the boards developed those principles into a draft standard. In June 2010, IASB and FASB published an Exposure Draft (ED) Revenue from Contracts with Customers, in consultation until October 22, 2010. After reviewing various aspects of the proposed ED, on the basis of the received comment letters, the boards decided to re-elaborate the proposals due to the importance to all involved in the financial reporting of revenue and the desire to avoid unintended consequences of the final standard. As a result, the Boards published the revised Exposure Draft Revenue from Contracts with Customers in November 2011 ("the 2011 ED"). After the received comments, there was a very wide, complex activity of revision, along with meetings and discussions with various users of financial statements, including buy-side and sell-side analysts. The paper was then reviewed and proposed to the Board in July 2013.

The standard aims to identify a single set of revenue recognition principles for every type of industry, and to develop logic of recognition of revenue founded on changes in assets and liabilities recognized in financial statements that can remove the inconsistencies and weaknesses in existing standards, in both US GAAP and IFRSs. They aim to do this by simplifying the preparation of financial statements reducing the number of requirements to which preparers must refer. For example, the revenue requirements in IAS 18 Revenue and IAS 11 Construction Contracts contain limited guidance on some topics, such as multiple-element arrangements, making the requirements difficult to apply to complex transactions. Moreover, the staff of the IFRS Foundation is aware of inconsistencies in the application of IFRIC 15 Agreements for the Construction of Real Estate due to the difficulty in determining when control of a good transfers over time. In contrast, US GAAP includes numerous and industry-specific requirements that often result in economically similar transactions being accounted for differently. The project also aims to improve disclosure requirements to make it easier for users to understand how an entity generates revenue and to compare revenue between entities. Users of financial statements commented that, given the importance of revenue, improvements to existing disclosure requirements are of critical importance as existing disclosure requirements are generally inadequate. The necessary steps to complete the joint standard have been taken so as to be in a position to finalize the proposal new standard. At the end of May 2014, the IASB and FASB issued the Standard Revenue from Contracts with Customers (IFRS 15 for IASB and Topic 606 for FASB), a single comprehensive framework for revenue recognition. The effective date for IFRS 15 was for annual reporting periods beginning on or after January 1, 2017, whereas Topic 606 had an effective date for public entities for annual reporting periods beginning after December 15, 2016.

It will be applied across transactions, industries and capital markets, and will improve comparability in the "top line" of the financial statements of companies, globally.

As described, disclosure requirements in previous IFRS and US GAAP often resulted in ambiguous and inadequate information, making it difficult for investors to understand a company's revenue, and the 
judgements and estimates made by the company in recognizing revenue. In IFRS, significant diversity in revenue recognition practices had arisen as previous revenue standards contained limited guidance on many important topics. Furthermore, the limited guidance that was provided was often difficult to apply to complex transactions. Consequently, some companies supplemented the limited guidance in IFRS by selectively applying US GAAP. However, in US GAAP, broad revenue recognition concepts were supplemented by numerous industry and transaction specific requirements, which often resulted in economically similar transactions being accounted for differently. The new standard on revenue recognitions has overcome these problems, improving the comparability of revenue from contracts with customers, reducing the need for interpretive guidance to be developed on a case-by-case basis to deal with emerging revenue recognition issues, and providing more useful information through improved disclosure requirements.

The core principle of the guidance is that an entity should recognize revenue to depict the transfer of promised goods or services to customers in an amount that reflects the consideration to which the entity expects to be entitled in exchange for those goods or services (FASB Revenue from Contracts with Customers). To achieve this aim, a company would apply a series of steps clearly described in the standards:

(1) Identify the contract(s) with a customer;

(2) Identify the performance obligations in the contract;

(3) Determine the transaction price;

(4) Allocate the transaction price to the performance obligations in the contract;

(5) Recognize revenue when (or as) the entity satisfies a performance obligation.

According to the Board, a contract is an agreement between two or more parties that creates enforceable rights and obligations. The first step for recognizing revenue states that a company can only recognize revenue if a contract with a customer exists. It is important that a company applies the standard to every contract with commercial substance, that each part can identify the contract terms and meet other important criteria.

The second step relates to the identification of the obligations in the contract. If the contract states that more than one good or service is promised to a customer, the company should account for each distinct good or service as a performance obligation. In determining whether a good or service is distinct, it is important to consider if the customers can benefit from the good or service on its own or together with other resources that are readily available to the customers. This notion represents an important key of the revenue recognition model that involves substantial judgment.

The third step is related to the identification of the transaction price as the amount of consideration to which a company expects to be entitled in exchange for transferring promised good or service to a customer. The transaction price can be a fixed amount or can vary.

In order to allocate the transaction price to the performance obligations in the contract (fourth step), when a contract contains more than one performance obligation, a company would typically allocate the transaction price to each performance obligation on the basis of the relative stand-alone selling prices of each distinct good or service. If the stand-alone selling price is not observable, the company should estimate it.

The last step concerns the recognized revenue when each separate performance obligation is satisfied. An entity must assess whether it is transferring control over time or at a point in time. For performance obligations that are satisfied over time, a company must measure progress toward its satisfaction. Instead, for performance obligations that are satisfied at a point in time, the company recognizes revenue at the point in time at which it transfers the control of the good or service to the customer. 
The standards give other specific indications on additional requirements, such as portfolio of contracts, contract costs and, to better help investors understand revenue in all their components, they require a company to disclose quantitative and/or qualitative information on its contracts with customers. Although the two common standards have reached the aim of achieving the same conclusions on all that is needed for accounting of revenue from contracts with customers, between the two there are some slight differences, regarding:

(1) Collectability threshold;

(2) Interim disclosure requirements;

(3) Early application and effective date;

(4) Impairment loss reversal;

(5) Non-public entity requirements.

However, the new standard will require significant management judgment - in addition to changing the way many companies recognize revenue in their financial statements. The changes will have pervasive impacts on people, policies, processes, and systems.

It should be mentioned that in June 2014, the IASB and FASB formed the Transition Resource Group (TRG) for revenue recognition to support implementation of the Standard.

The group periodically meets in public to discuss potential issues arising from the implementation of the new revenue recognition standard (IFRS 15/ASU Topic 606).

Its principal objectives are:

(1) Stress, analyzing and debating issues of stakeholders resulting from the implementation of the new standards;

(2) Notify the IASB and FASB on these implementation issues, which will help the boards to determine what, if any, action will be necessary to address these issues;

(3) Provide a forum for stakeholders to know the new standard from others involved in the implementation.

The TRG also helps stakeholders to better understand specific aspects of the new revenue standard.

However, after discussions in the working group, many are facing significant challenges in implementing the requirements, and for this reason, the IASB decided to propose some amendments to IFRS 15 and postpone the date of mandatory application of the principle to January 1, 2018 in order to allow companies to directly apply the amended standard.

\section{Practice of Disclosing Information About the Consequences of Implementing IFRS 15 in Financial Statements of Polish Banks}

The banking sector in Poland is composed of more than 600 units. However, reports from the Polish Financial Supervision Authority (FSA) show that the share in assets or deposits of the five largest banks in Poland reaches $50 \%$ of the total values for the entire banking sector. ${ }^{6}$ Both the FSA report, which describes the situation of Polish banks in 2015 (Kotowicz, 2015), and the "Financial Monthly" ranking, state that the Top 5 banks in terms of best results achieved in the first quarter of 2016 (starting with the best) are (Miesięcznik Finansowy Bank, 2016):

(1) PKO BP;

\footnotetext{
${ }^{6}$ Retrieved from https://www.knf.gov.pl/opracowania/sektor_bankowy/dane_o_rynku/Dane_miesieczne.html. Names of the biggest banks, as stated by KNF, are not given in the report.
} 
(2) Pekao S.A.;

(3) BZ WBK;

(4) mBank;

(5) ING Bank Śląski.

All listed banks prepare financial statements in accordance with IFRS. The information contained in the statements of these banks, which is of key importance for the banking sector in Poland, will be examined.

Table 1

Presentation of Information About IFRS 15 Contained in the Financial Statements of the Examined Banks

\begin{tabular}{|c|c|c|c|c|c|c|c|c|}
\hline \multirow[t]{2}{*}{$\begin{array}{l}\text { Name of } \\
\text { bank }\end{array}$} & \multicolumn{2}{|c|}{$\begin{array}{l}\text { Information } \\
\text { about the date of } \\
\text { implementation }\end{array}$} & \multicolumn{2}{|c|}{$\begin{array}{l}\text { Overview of the } \\
\text { basic principles } \\
\text { of the standard }\end{array}$} & \multicolumn{2}{|c|}{\begin{tabular}{|c|} 
Including \\
information on \\
IFRS 15 in a \\
specific part of \\
explanatory \\
notes \\
\end{tabular}} & \multicolumn{2}{|c|}{$\begin{array}{l}\text { Information on the impact implementation of IFRS } 15 \text { has on } \\
\text { financial statements }\end{array}$} \\
\hline & 2015 & 2016 & 2015 & 2016 & 2015 & 2016 & 2015 & 2016 \\
\hline PKO BP & + & - & + & + & $\mathrm{a}$ & $b$ & $\begin{array}{l}\text { The bank concludes that the } \\
\text { implementation of IFRS 15 } \\
\text { may result in changes in } \\
\text { revenue accounting over a } \\
\text { period and will require } \\
\text { additional disclosures in the } \\
\text { financial statements }\end{array}$ & $\begin{array}{l}\text { The bank supposes that the } \\
\text { impact on its financial } \\
\text { statements should not be } \\
\text { significant }\end{array}$ \\
\hline Pekao & + & + & + & + & $\mathrm{a}$ & $a$ & $\begin{array}{l}\text { The group is in the process of } \\
\text { evaluating the impact of } \\
\text { IFRS } 15 \text { on its financial } \\
\text { statements }\end{array}$ & $\begin{array}{l}\text { The group is in the process of } \\
\text { evaluating the impact of } \\
\text { IFRS } 15 \text { on its financial } \\
\text { statements }\end{array}$ \\
\hline BZ WBK & + & + & - & + & c & c & $\begin{array}{l}\text { The group has not completed } \\
\text { the analysis of changes }\end{array}$ & $\begin{array}{l}\text { The group does not expect a } \\
\text { significant impact on how } \\
\text { revenue is recognized }\end{array}$ \\
\hline mBank & + & + & + & + & $\mathrm{a}$ & $a, b$ & $\begin{array}{l}\text { The group believes that } \\
\text { applying the standard will not } \\
\text { have a significant impact on } \\
\text { the financial statements } \\
\text { during its initial application }\end{array}$ & $\begin{array}{l}\text { a: No information was } \\
\text { provided on the impact on } \\
\text { financial statements } \\
\text { b: The bank believes that the } \\
\text { adoption of the standard will } \\
\text { not have a significant impact } \\
\text { on the financial statements } \\
\text { during its initial application }\end{array}$ \\
\hline $\begin{array}{l}\text { ING Bank } \\
\text { Śląski }\end{array}$ & + & + & - & - & $a$ & $a, b$ & $\begin{array}{l}\text { An analysis shows that the } \\
\text { implementation will not have } \\
\text { a significant impact on the } \\
\text { financial statements of the } \\
\text { group }\end{array}$ & $\begin{array}{l}\text { a: An analysis shows that } \\
\text { the implementation will not } \\
\text { have a significant impact on } \\
\text { the financial statements of the } \\
\text { group } \\
\text { b: The group is in the process } \\
\text { of analyzing the impact of } \\
\text { amendments to the standard } \\
\text { on the group's financial } \\
\text { statements. The first analysis } \\
\text { shows that the implementation } \\
\text { of the change will not have a } \\
\text { significant impact on the } \\
\text { group's financial statements }\end{array}$ \\
\hline
\end{tabular}

Notes. Description of letter symbols: a: Recording information on IFRS 15 in respect to new standards published by the IASB but not approved by the EU; b: Recording information on IFRS 15 in respect to new standards approved by the EU but not yet in use; c: Recording information on IFRS 15 in consolidated statements in reference to new standards and interpretations and amendments to standards and interpretations, that may be applied for a group and are not yet in use and have not been introduced. Source: own study, on the basis of the financial statements of selected banks. 
The main purpose of the study is to answer the question whether banks' financial statements contain prospective information. An intended change is the implementation of IFRS 15. Therefore, information on the implementation of IFRS 15 and the anticipated consequences of this implementation as well as changes in the financial statements will be the subject of analysis. Consolidated financial statements for the years 2015-2016 will be examined. The 2-year study period will also allow for identification of any changes during the implementation of IFRS 15 and to anticipate the potential consequences of the implementation of this standard on the accounting of the analyzed banks.

In the course of research, widely available on-line financial statements for the years 2015-2016 of the aforementioned banks were obtained, followed by a thorough examination of all information on IFRS 15 contained in the financial statements. In all analyzed cases, explanatory notes to the financial statements contained information on IFRS 15. A synthetic summary of the information presented is given in Table 1 .

The key rule to IFRS 15 is to record revenue in such a way as to recognize the transfer of goods or services to customers in the amount corresponding remuneration (i.e., the payment) that the company expects to receive in exchange for those goods or services. According to IFRS 15, revenue is generated when the control over goods or services is passed onto the customer.

In four of the analyzed cases, there was a reference to the general principles of IFRS 15 that may affect banks' financial statements. Additionally, in one of the cases (BZ WBK), there is mention of changes to areas which IFRS 15 will affect (i.e., transfer of control, variable remuneration, allocation of transaction price based on unit sales price, licenses and time value of money). In one of the cases analyzed (ING Bank Śląski), no information was provided about the basic - from the bank's point of view - changes resulting from the standard. In another case (mBank), there is no reference in the financial statements whether changes resulting from the implementation of IFRS 15 will affect the financial statements. In this case, only the impact of the amendment to IFRS 15 was addressed, amendment which has not yet been approved by the EU.

IFRS 15, as an example, highlights the individualism in approach to the presentation of potential changes resulting from the standard. The individualism in presentation concerns issues such as:

(1) The presentation of publication dates, the approval or planned implementation of standard;

(2) The amount of detail in standard description;

(3) IFRS 15 presentation in financial statements from 2016 in respect parts which include standards approved or not approved by the EU, or both, ${ }^{7}$

(4) The differences at the time of completion of the analysis of the potential impact of IFRS 15 on the financial statements $(2015,2016$ or not finalized by the end of 2016).

Undoubtedly, it is worth noting that all banks have already indicated work on the implementation of the new standard in the financial statements for 2015. The non-uniformity in recording information about IFRS 15 may, however, raise reservations in the context of the transparency of banks' financial statements.

\section{Conclusions}

The overriding objective of creating IAS/IFRS and their implementation within the EU is to standardize accounting rules utilized by companies and other organizations. Poland, as a member of the EU, introduced mandatory use of IAS in the preparation of consolidated financial statements of listed companies and banks in 2005.

\footnotetext{
${ }^{7} \mathrm{BZ}$ WBK is a different case since all planned changes in standards are displayed in a single statement - both approved and not approved by the EU.
} 
At the same time, it should be stated that for entities operating in Poland, IFRSs are difficult. The construction of IFRS is different from the construction and content of the Polish accounting law. In addition, IFRSs contain significantly more difficult procedures for the identification, valuation, and disclosure of economic events. As a consequence, the complexity of IFRS is a challenge for both accountants and statutory auditors in Poland. Moreover, the philosophy underlying IFRS assumes that individuals will strive to present a true and reliable picture of their financial situation in the financial statements. However, in Poland there is a tendency to not disclose inconvenient information (Wędzki, 2009).

Another challenge for accounting professionals and users of financial statements is the evolution of the International Financial Reporting Standards. Undoubtedly, changes to existing standards and the creation of new ones are necessary in order to reflect the complexity of economic life in the financial communicating planned changes in entities using IAS/IFRS will involve the disclosure of the analyzed impact on the financial statements in advance. Leaving great freedom (as for Polish norms) may involve a differentiated approach to disclosing information about IFRS being implemented. At the same time, financial statements of banks, as entities of public trust, should be exceptionally diligent in disclosing relevant information.

One of the currently implemented international standards is IFRS 15, which also applies to banks. Empirical studies have indicated a heterogeneous approach to determining the potential impact of the standard being implemented and how the impact is presented in the financial statements. The results of the study also indicate different stages of work on the analysis of potential changes resulting from IFRS 15. It is worth noting that, in all studied cases, work on the implementation of the new standard was observed. However, discrepancies in how information about IFRS 15 is presented may be an obstacle for users of banks' financial statements.

Financial statements drawn up in accordance with accounting principles, and even with IFRS, allow some flexibility in the area of valuation and presentation of data. The research is aimed at raising awareness among users of financial statements on the heterogeneous approach to the presentation of information, even in banks, which are institutions of great importance to the financial system of each country.

Functioning in the information age, connected with a significant role of the virtualization of accounting information of an entity - emphasized in research (Baran \& Bauer, 2016; Bauer \& Baran, 2015), changes in the storage and retrieval of accounting data of banks (Bátiz-Lazo \& Wood, 2002) and indicated limited access to financial reporting of cooperative banks in Poland (Bauer, 2015), shows the need for research related to financial information of banks.

The focus in this article is put on the way data are presented about work on the implementation of IFRS 15 and how banks estimate the impact of the new IFRS 15 on their financial statements. Research will continue. Further study will explore potential implications that IFRS 15 implementation might bring about for banks' accounting.

\section{References}

Afonso, G., Santos, J. A., \& Traina, J. (2014). Do “too-big-to-fail” banks take on more risk? Economic Policy Review, 20(2), 41-58. Bank Gospodarstwa Krajowego [BGK]. (2015). Annual report 2015. Retrieved from https://www.bgk.pl/files/public/Pliki/O_Banku/Bank_w_liczbach/Raport_roczny/Raport_roczny_BGK_za_2015_r.pdf

Baran, M., \& Bauer, K. (2016). Wkraczając w erę informacji: outsourcing usług księgowych w sektorze MSP w perspektywie oczekiwań interesariuszy. In A. Kuzior, \& A. Szewieczek (Eds.), Wspótczesne problemy i kierunki transformacji rachunkowości i rewizji finansowej (T. 1, pp. 18-27). Wydawnictwo Uniwersytetu Ekonomicznego w Katowicach, Katowice. doi: 10.14419/ijaes.v3i2.5194. 
Barth, M. E., Landsman, W. R., Lang, M. H., \& Williams, C. D. (2012). Are IFRS-based and US GAAP-based accounting amounts comparable? Journal of Accounting and Economics, 54(1), 68-93.

Bátiz-Lazo, B., \& Wood, D. (2002). An historical appraisal of information technology in commercial banking. Electronic Markets, $12(3), 192-205$.

Bauer, K. (2015). Regulatory conditions of cooperative banks' financial reporting in Poland. In Wspótczesne uwarunkowania sprawozdawczości i rewizji finansowej (pp. 13-23). Fundacja Uniwersytetu Ekonomicznego, Kraków.

Bauer, K., \& Baran, M. (2015). Virtualization of information as the direction of development of accounting support systems. Empirical evidence from Poland. International Journal of Accounting and Economics Studies, 3(2), 128-134.

Berger, A. N., Klapper, L. F., \& Turk-Ariss, R. (2009). Bank competition and financial stability. Journal of Financial Services Research, 35(2), 99-118.

Boyd, J. H., \& Heitz, A. (2016). The social costs and benefits of too-big-to-fail banks: A "bounding” exercise. Journal of Banking \& Finance, 68, 251-265.

Brewer, E., \& Jagtiani, J. (2013). How much did banks pay to become too-big-to-fail and to become systemically important? Journal of Financial Services Research, 43(1), 1-35.

Bujnowicz, I. (2008). Teoretyczne podstawy wyróżnienia systemów finansowych we współczesnej gospodarce rynkowej-wybrane aspekty. Acta Universitatis Lodziensis. Folia Oeconomica 221.

Carletti, E., \& Hartmann, P. (2003). Competition and financial stability: What's special about banking? In P. Mizen (Ed.), Monetary history, exchange rates and financial markets: Essays in honour of Charles Goodhart (Vol. 2). Edward Elgar, Cheltenham, UK.

Carmona, S., \& Trombetta, M. (2010). The IASB and FASB convergence process and the need for 'concept-based' accounting teaching. Advances in Accounting, Incorporating Advances in International Accounting, 26(1), 1-5.

Choi, F. D. S., Frost, C. A., \& Meek, G. K. (2002). International accounting (4th ed.). Upper Saddle River, New Jersey, NJ: Pearson Education, Inc..

Cwynar, W., \& Patena, W. (2010). Podręcznik do bankowości. Rynki, regulacje, ustugi. Wolters Kluwer Polska, Warszawa.

Demirgüç-Kunt, A., \& Huizinga, H. (2013). Are banks too big to fail or too big to save? International evidence from equity prices and CDS spreads. Journal of Banking \& Finance, 37(3), 875-894.

Gostomski, E. (2008). Konwergencja modeli. Gazeta Bankowa, 39(1039), 24-26.

Jorissen, A., Lybaert, N., \& Van De Poel, K. (2006). Lobbying towards a global standard setter - Do national characteristics matter? An analysis of the comment letters written to the IASB. In G. N. Gregorious, \& G. Gaber (Eds.), International accounting: Standards, regulation, and financial reporting. Elsevier, Oxford.

Kotowicz, A. (2015). Raport o sytuacji banków w 2015 roku. In cooperation with Departament Bankowości Komercyjnej i Specjalistycznej oraz Instytucji Płatniczych, Urząd Komisji Nadzoru Finansowego, Warszawa 2016. Retrieved from https://www.knf.gov.pl/Images/RAPORT_O_SYTUACJIBANKOW_2015_tcm75-47215.pdf

Krasodomska, J. (2010). Anglosaski i kontynentalny model rachunkowości na przykładzie wybranych krajów. Zeszyty Teoretyczne Rachunkowości, 55(111), 119-138.

Krasodomska, J. (2015). Specyfika regulacji w zakresie sprawozdawczości banków, jako jednostek zainteresowania publicznego. In B. Micherda (Ed.), Specyfika regulacji w zakresie rachunkowości jednostek zainteresowania i pożytku publicznego (pp. 110-133). Difin, Warszawa.

Marcinkowska, M. (2007). Ocena działalności instytucji finansowych. Difin, Warszawa.

Othman, H. B., \& Zeghal, D. (2006). A study of earnings-management motives in the Anglo-American and Euro-Continental accounting models: The Canadian and French cases. The International Journal of Accounting, 41(4), 406-435.

Surdykowska, S. T. (2012). Ryzyko finansowe $w$ środowisku globalnej gospodarki. Kulisy najbardziej spektakularnych afer finansowych ostatnich lat. Difin, Warszawa.

The Conceptual Framework for Financial Reporting. (2017). eIFRS. The blue book. Retrieved from http://eifrs.ifrs.org/eifrs/ViewContent?collection=2017_Blue_Book\&fn=Conceptual_Framework_HTML_USE_ONLY.html \&scrollTo $=$ F15147653

Tominac, S. B., \& Palijan, A. (2015). Operational risk management in Croatian banks. Paper presented at the 15th EBES Conference, Lisbon.

Tominac, S. B., \& Palijan, A. (2016). Managing operational risk in banks: Croatian case, Proceedings of the MAC-MME 2016 (pp. 134-138), MAC Prague Consulting. 
Turner, L. E. (2001). Revenue recognition. Remarks by Chief Accountant of SEC, delivered at the USC SEC and Financial Reporting Institute, Los Angeles, CA, May 31, 2001. Retrieved from http://www.sec.gov/news/speech/spch495.htm

Ustawa z dnia 29 sierpnia 1997 r. Prawo bankowe, J. L. 1997, No. 140, poz. 939, along with all amendments.

Ustawa z dnia 29 września 1994 r. o rachunkowości, J. L. 1994, No. 121, Item 591, along with all amendments.

Ustawa z dnia 7 maja 2009 o biegłych rewidentach i ich samorządzie, podmiotach uprawnionych do badania sprawozdań finansowych oraz o nadzorze publicznym, J. L. 2009, No. 77, Item 649, along with all amendments.

Wędzki, D. (2009). Analiza sprawozdania finansowego. Tom 1. Sprawozdanie finansowe. Pozycje sprawozdania jednostkowego, skonsolidowanego, dla GUS, raportów spółek giełdowych oraz sprawozdania wedlug Międzynarodowych Standardów Sprawozdawczości Finansowej. Wolters Kluwer Polska, Kraków.

Wójcik-Jurkiewicz, M. (2015). Diagnoza stosowania praktyk proekologicznych i proetycznych w bankach komercyjnych na przykładzie ING Bank Ślaski SA. In L. Podkaminera (Ed.), Instytucjonalne uwarunkowania systemu finansowego jako środowiska rozwoju sfery realnej (pp. 206-217). Wydawnictwo: Wyższa Szkoła Finansów i Prawa (Bielsko-Biała).

Wszelaki, A. (2014). Różnice w sporządzaniu sprawozdania finansowego banku według Ustawy o rachunkowości i Międzynarodowych Standardów Sprawozdawczości Finansowej. Zeszyty Naukowe Uniwersytetu Szczecińskiego. Finanse, Rynki Finansowe, Ubazpieczenia, 71, 159-172.

Zengin, S., \& Yuksel, S. (2016). A comparison of the views of internal controllers/auditors and branch/call center personnel of the banks for operational risk: A case for Turkish banking sector. International Journal of Finance \& Banking Studies, 5(4), $10-29$.

Zhang, Y. (2005). Revenue recognition timing and attributes of reported revenue: The case of software industry's adoption of SOP 91-1. Journal of Accounting and Economics, 39(3), 535-561.

Zieliński, T. (2013). Współczesny bank wobec paradygmatu zaufania publicznego. Annales Universitatis Mariae Curie-Skłodowska. Sectio H. Oeconomia, 47(3), 673-683. 